Department of Public Health, Policy and Systems, University of Liverpool, Liverpool, UK

Correspondence to: $\mathrm{M}$ Whitehead mmw@liverpool.ac.uk Cite this as: BMJ 2021;372:n376 http://dx.doi.org/10.1136/bmj.n376 Published: 11 February 2021

\section{Poverty, health, and covid-19}

\section{Yet again, poor families will be hardest hit by the pandemic's long economic fallout}

\section{Margaret Whitehead, David Taylor-Robinson, Ben Barr}

Covid-19 does not strike at random-mortality is much higher in elderly people, poorer groups, and ethnic minorities, and its economic effect is also unevenly distributed across the population. The economic fallout is likely to be felt for years. Without concerted preventive action worse off families and communities will be disproportionately affected, increasing health inequalities in the UK and globally.

Even before covid-19, extremely disturbing trends in health were emerging in England. Growing child poverty, homelessness, and food poverty led to an unprecedented rise in infant mortality, mental health problems, and stalling life expectancy, especially for women in the poorest areas and cities. ${ }^{1}$ These were the same areas where 10 years of austerity measures had hit the poorest groups the hardest. Larger cuts in government funding to local authorities with higher proportions of children in poverty meant a reduction in spending on vital preventive services in areas where they were needed most. ${ }^{2}$ The pandemic arrived in the middle of this worrying scene and amplified existing inequalities.

Exposure to infection is unequal. People in precarious, low paid, manual jobs in the caring, retail, and service sectors have been more exposed to covid-19 as their face-to-face jobs cannot be done from home. ${ }^{3}$ Overcrowded, poor quality housing in densely populated areas have often added to their increased risk. ${ }^{4}$ Poorer communities have also been more vulnerable to severe disease once infected because of higher levels of pre-existing illness. Increased rates of infection have led to greater loss of income linked to disruptions to work and job loss, but the immediate financial pressure of covid-19 has gone far beyond this.

Containment and lockdown measures have disproportionately affected low income families with young children. ${ }^{5}$ Recent research identified the extra costs involved in having children at home for longer without access to vital free services, requiring increased spending on food, heating, and occupying children indoors. Over a third of low income families with children increased their spending during 2020, while $40 \%$ of high income families without children reduced theirs. ${ }^{6}$

Rising demand for universal credit exposed the inadequacy of current levels of benefits. The UK government increased universal credit payments by $€ 20$ ( $€ 23 ;$ \$28) a week to compensate for extra expenses during lockdown, but as yet the increase is only temporary. Food poverty increased, with free school meals-an essential nutritional boost for many low income families-having to be replaced by emergency measures to prevent children going hungry during school closures. Government support for this scheme has been precarious, and at times the measures have been inadequate to maintain the health of growing children.

\section{Long term forecast}

Predicted long term economic effects include loss of future earnings and unemployment, pushing more adults, particularly parents, into poverty. The effect of the pandemic on employment is predicted to be 10 times greater than that of the 2008 financial crisis, ${ }^{8}$ which led to a sharp increase in suicides and mental illness. ${ }^{9}$ The pandemic induced recession is likely to have a similarly damaging effect on mental health.

By far the most devastating long term costs of the pandemic are likely to fall on today's children as they grow, develop, and forge their own economic futures. ${ }^{25}$ Child poverty is already the biggest threat to child health and development in the UK and globally, ${ }^{10}$ so the predicted increase is concerning. ${ }^{11}$ A combination of worse financial strain within families and stay-at-home pandemic policies is causing immediate harm to the development and mental health of children, with some younger children regressing in basic skills. ${ }^{12}$ Currently, one in six children and young people have mental health problems ${ }^{13}$ as their lives are "put on hold," with clear implications for their long term health and earnings.

Lost learning will cause the greatest damage to the qualifications and job prospects of pupils who are already disadvantaged. Calling for a "massive national policy response," 14 the Institute for Fiscal Studies estimated that missing half a year of school could mean losing $£ 40$ ooo in lifetime earnings, with negative effects concentrated among children from disadvantaged backgrounds.

The common framing of action as a trade-off between protecting health or protecting the economy is a false dichotomy: international evidence shows that the virus must be under control for the economy to recover. ${ }^{15}$ We need to protect the worse off in society from the adverse consequences falling disproportionately on them, especially by giving every child the best start in life. This could include, in the immediate future, retaining the universal credit uplift, raising the pupil premium, and introducing intensive measures to help disadvantaged pupils catch up on lost learning, including addressing the digital divide.

In the medium term, the large numbers of people out of work and those whose ability to work is reduced because of the long term effects of covid-19 will need effective support and training to return to work. Reinvesting in children's preventive services such as Sure Start children's centres and improved access to a range of mental health services will be crucial. But 
above all we must avoid reintroducing austerity measures to fix the economy, which would again fall heaviest on the most disadvantaged groups and communities, widening health inequalities still further. Instead, we must "build back fairer."16

Competing interests: We have read and understood BMJ policy on declaration of interests and have no interests to declare.

Provenance and peer review: Commissioned; not externally peer reviewed.

1 Taylor-Robinson D, Barr B, Whitehead M. Stalling life expectancy and rising inequalities in England. Lancet 2019;394:2238-9. doi: 10.1016/S0140-6736(19)32610-8. pmid: 31868623

2 Bambra C, Monford L, Alexiou A, et al. COVID-19 and the Northern Powerhouse. Northern Health Science Alliance, 2020. https://www.thenhsa.co.uk/app/uploads/2020/11/NP-COVID-REPORT101120-.pdf.

3 Whitehead M, Taylor-Robinson D, Barr B. Covid-19: We are not "all in it together"-less privileged in society are suffering the brunt of the damage. BMJ Opinion 22 May 2020

https://blogs.bmj.com/bmi/2020/05/22/covid-19-we-are-not-all-in-it-together-less-privileged-insociety-are-suffering-the-brunt-of-the-damage/

4 Daras K, Alexiou A, Rose TC, Buchan I, Taylor-Robinson D, Barr B. How does vulnerability to covid-19 vary between communities in England? Developing a small area vulnerability index (SAVI). Social Science Research Network 2020. [Preprint.] doi: 10.2139/ssrn.3650050

5 Hefferon C, Taylor C, Bennett D, etal. Priorities for the child public health response to the COVID-19 pandemic recovery in England. Arch Dis Child 2020;9:archdischild-2020-320214. doi: 10.1136/archdischild-2020-320214. pmid: 33298551

6 Brewer M, Patrick R. Pandemic pressures: why families on low income are spending more during covid-19. Resolution Foundation, 2021, https://www.resolutionfoundation.org/publications/pandemic-pressures/

7 Baraniuk C. Fears grow of nutritional crisis in lockdown UK. BMJ2020;370:m3193. doi: 10.1136/bmj.m3193 pmid: 32819891

8 OECD. Employment outlook 2020.http://www.oecd.org/employment-outlook/2020/

9 Barr B, Taylor-Robinson D, Scott-Samuel A, McKee M, Stuckler D. Suicides associated with the 2008-10 economic recession in England: time trend analysis. BM/2012;345:e5142-5142. doi: 10.1136/bmj.e5142. pmid: 22893569

10 Unicef. COVID-19 impacts on child poverty. 2020. https://www.unicef.org/social-policy/childpoverty/covid-19-socioeconomic-impacts

11 Francis-Devine B. Poverty in the UK: statistics. House of Commons Library, 2021. https://commonslibrary.parliament.uk/research-briefings/sn07096/

12 Ofsted Chief Inspector. "We cannot furlough young people’s learning." Education in the media. https://dfemedia.blog.gov.uk/2021/01/03/ofsted-chief-inspector-we-cannot-furlough-youngpeoples-learning/

13 NHS Digital. Mental health of children and young people in England, 2020: Wave 1 follow up to the 2017 survey. NHS Digital, 2020. https://digital.nhs.uk/data-and-information/publications/statistical/mental-health-of-children-and-young-people-in-england/2020-wave-1-follow-up

14 Sibieta L. The crisis in lost learning calls for a massive national policy response. Institute for Fiscal Studies, 2021, https://www.ifs.org.uk/publications/15291

15 Aum S, Lee SY, Shin Y. Inequality of fear and self-quarantine: is there a trade-off between GDP and Public Health? Centre for Economic Policy Research, 2020 https://ideas.repec.org/p/cpr/ceprdp/14679.html.

16 Marmot M, Allen J, Goldblatt P, Herd E, Morrison J. Build back fairer: the covid-19 Marmot review. Institute of Health Equity, 2020, http://www.instituteofhealthequity.org/about-our-work/latestupdates-from-the-institute/build-back-fairer

This article is made freely available for use in accordance with BMJ's website terms and conditions for the duration of the covid-19 pandemic or until otherwise determined by BMJ. You may use, download and print the article for any lawful, non-commercial purpose (including text and data mining) provided that all copyright notices and trade marks are retained. 